\title{
19. STRUCTURES IN PERIDOTITES FROM SITE 895, HESS DEEP: IMPLICATIONS FOR THE GEOMETRY OF MANTLE FLOW BENEATH THE EAST PACIFIC RISE ${ }^{1}$
}

\author{
F. Boudier, ${ }^{2}$ C.J. MacLeod, ${ }^{3}$ and L. Bolou ${ }^{2}$
}

\begin{abstract}
Drilling at Site 895 in the Hess Deep provided 200-m sections of interlayered harzburgites, dunites (containing interstitial clinopyroxene and plagioclase), and troctolites, similar in lithology and overall stratigraphic organization to Moho transition zones reported in ophiolite complexes such as Oman. Similar lithologies previously collected from the East Pacific Rise have been described as mantle rocks within which "impregnated" melt has become entrapped. Our textural studies of the Site 895 specimens confirm this interpretation, based upon the deformation and annealing of the peridotite framework contrasting with the lack of deformation in the interstitial phases. High dislocation densities in all the different lithologies emphasize the residual character of the olivine crystals.

For the first time ever in an in situ section of oceanic mantle peridotites, the orientations of the deformation fabrics in the peridotites, and hence the geometry of mantle flow, have been restored to geographical coordinates (with reference to stable magnetic remanence directions). The oriented fabrics show that mantle shear plane is moderately to steeply dipping and that it strikes parallel to the East Pacific Rise axis. This relationship is particularly consistent in the harzburgites but less so in the massive dunites from Hole 895E, within which the dip of the foliation decreases systematically toward the top of the section and the lineation plunge directions become scattered. We interpret this geometry as representing the fossilized top of a diapir that ascended beneath the EPR and, it would appear, started to overturn in a melt-charged transition zone at the crust/mantle boundary. Although such a flow geometry might normally be expected to be destroyed by continued upwelling and lithospheric expansion, we speculate that the structures observed were frozen in by rapid cooling and uplift of the EPR lithosphere in the Hess Deep rift valley by the propagation of the Cocos-Nazca Spreading Center.
\end{abstract}

\section{INTRODUCTION}

The Hess Deep is a 5400-m-deep rift valley located at the triple junction between the Pacific, Cocos, and Nazca Plates. In the Hess Deep, oceanic lithosphere formed by accretion at the fast-spreading, north-trending East Pacific Rise (EPR) is being rifted and dismembered ahead of the westward-propagating, east-trending CocosNazca Ridge (CNR) (Johnson et al., 1976; Hey et al., 1977; Lonsdale, 1988; Searle and Francheteau, 1986).

First sampled by dredging (Kashintsev et al., 1982), the site was explored using the submersible Nautile (Francheteau et al., 1990), yielding samples of the variety of rocks that are thought to represent the EPR oceanic lithosphere; among them, clinopyroxene- and plagioclase-bearing dunites and harzburgites have been described and interpreted as mantle rocks impregnated by interstitial melt $(\mathrm{Gi}-$ rardeau and Francheteau, 1993; Hekinian et al., 1993).

Ocean Drilling Program Site 895 is located on the southern slope of intra-rift ridge, along Section NZ 17 of the Nautile survey (Hekinian et al., 1993), which exposes a recurrent succession of harzburgite, dunite, gabbronorite, and rodingitized gabbro (Fig. 1A). The six holes of Site 895 are located on an ultramafic outcrop near the base of the section. They were penetrated to $17.2 \mathrm{~m}$ at Hole $895 \mathrm{~A}, 10.3 \mathrm{~m}$ at Hole 895B, $37.9 \mathrm{~m}$ at Hole $895 \mathrm{C}, 93.7 \mathrm{~m}$ at Hole $895 \mathrm{D}, 87.6 \mathrm{~m}$ at

'Mével, C., Gillis, K.M., Allan, J.F., and Meyer, P.S. (Eds.), 1996. Proc, ODP, Sci Results, 147: College Station, TX (Ocean Drilling Program).

${ }^{2}$ Laboratoire de Tectonophysique, ISTEEM, Université de Montpellier 2, F-34095 Montpellier Cedex 05, France. Boudier: fran@dstu.univ-montp2.fr

${ }^{3}$ Department of Earth Sciences, University of Wales College of Cardiff, P.O. Box 914, Cardiff CF1 3YE, United Kingdom. Formerly at: Institute of Oceanographic Sciences, Brook Road, Wormley, Surrey GU8 5UB, United Kingdom; and Borehole Research, Department of Geology, University of Leicester, Leicester LE1 7RH, United Kingdom.
Hole $895 \mathrm{E}$, and $26.2 \mathrm{~m}$ at Hole $895 \mathrm{~F}$, over a horizontal distance of $500 \mathrm{~m}$ from south to north (Fig. 1B). The rocks recovered are dominantly harzburgite in Holes $895 \mathrm{C}$ and $895 \mathrm{D}$, dominantly dunite in Hole $895 \mathrm{E}$. Clinopyroxene- and plagioclase-bearing ultramafics of the type described from the Nautile survey (Girardeau and Francheteau, 1993; Hekinian et al., 1993) were the principal rock types recovered. In addition to the textural information, the cores drilled provide two stratigraphic sections each of almost $100 \mathrm{~m}$ thick in the peridotites of the Hess Deep, and, in particular, show that ultramafic and mafic rocks may be interlayered at a scale of tens of centimeters to tens of meters. This type of layering has not previously been recognized in ocean-floor peridotites, but has been described at the Moho transition zone of some ophiolites (e.g., Oman; Browning, 1984; Benn et al., 1988; Boudier and Nicolas, 1995).

In this paper, we incorporate and built on the numerous measurements of foliations in Site 895 peridotites obtained during Leg 147 (Gillis, Mével, Allan, et al., 1993), and present complementary measurements (mainly spinel lineations) made on quarter-round cores in the laboratory post-cruise. We have been able to restore many measurements to geographical (magnetic) coordinates using new paleomagnetic data made by the post-cruise studies of P. Kelso, J. Pariso, and C. Richter, as well as the shipboard measurements of stable magnetic remanence direction given in Gillis, Mével, Allan, et al. (1993). Four specimens representative of the principal rock types recovered were selected for complete textural and fabric study.

\section{TEXTURES AND FABRICS}

The peridotites from the Hess Deep differ from most peridotites dredged in the oceans (Dick and Bullen, 1984), in that they include a large representation of harzburgites and dunites bearing clinopyroxene and plagioclase (albeit deeply altered) as interstitial phases. Such 


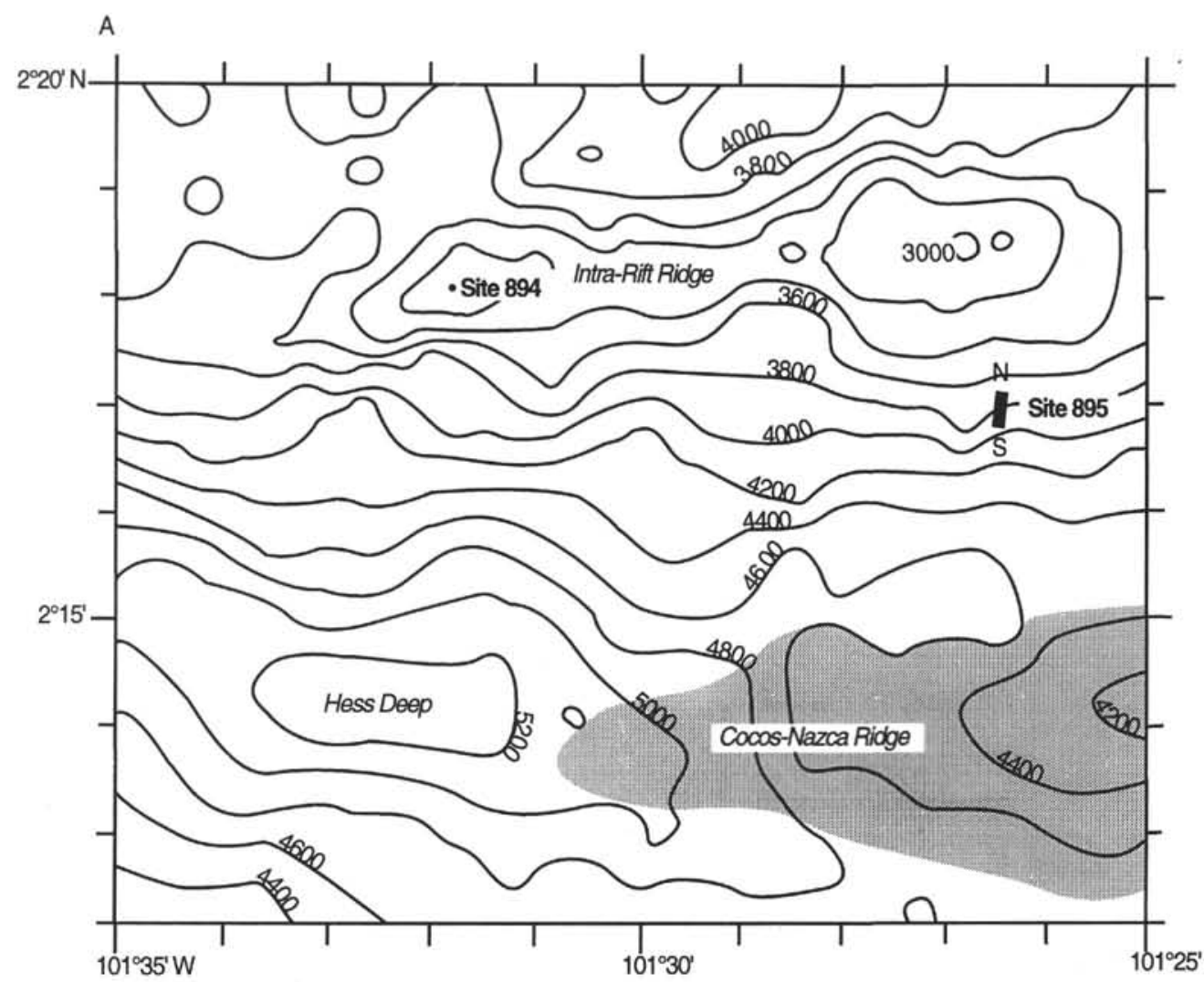

B

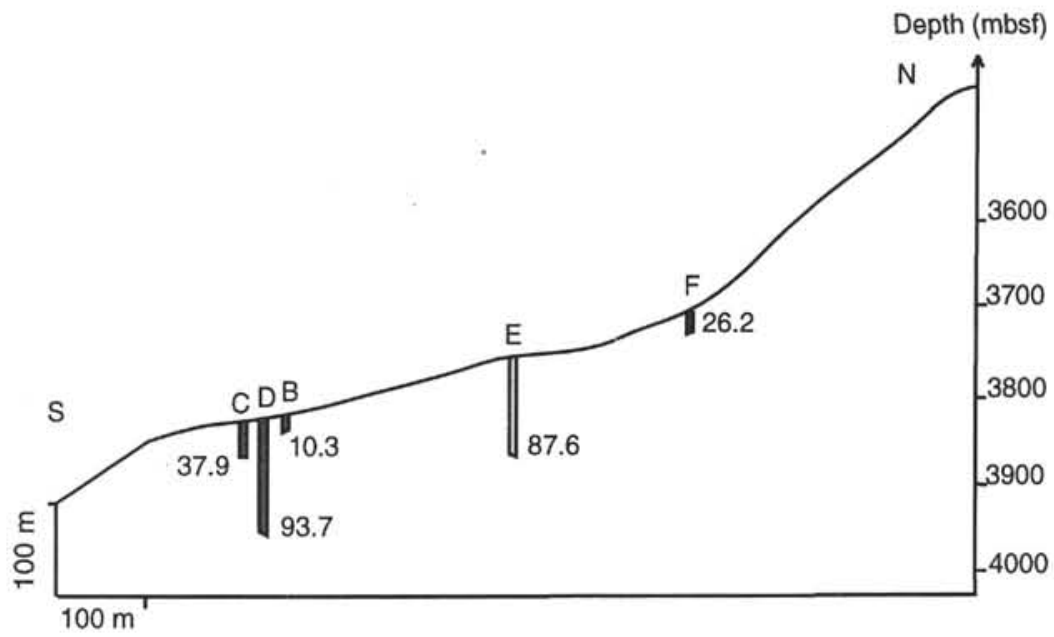

Figure 1. A. Location map of Site 895 (box) on the southern slope of the intra-rift ridge, Hess Deep. Bathymetry is from SeaBeam data taken from Gillis, Mével, Allan, et al. (1993). B. Cross-section of Site 895 with location of Holes 895B, 895C, 895D, 895E, and 895F. Black column, dunite dominant; white column, harzburgite dominant.

rocks have previously been collected only from the Garrett Fracture Zone on the southern EPR (Hébert et al., 1983; Cannat et al., 1990), during the Nautile submersible survey of the Hess Deep (Girardeau and Francheteau, 1993; Hekinian et al., 1993), and from Deep Sea Drilling Project Site 334 on the Mid-Atlantic Ridge (Girardeau and Mercier, 1992). They have been interpreted as mantle peridotites impregnated by melt, based on evidence for large high-T plastic deformation in olivine, but its complete absence in the interstitial phases, and by reference to similar rocks described at the Moho transition zone of the Oman ophiolite (Nicolas, 1986; Benn et al., 1988; Boudier and Nicolas, 1995).
To explore the similarities and compare the Leg 147 samples with other oceanic peridotites of the same type, we have followed a similar microstructural approach to that proposed by Cannat et al. (1990) and Girardeau and Francheteau (1993). The aim of this study is to identify evidence for and the mechanisms of plastic deformation in the peridotites, evaluating the intensity of this deformation, and determining its timing relative to the magmatic processes that led to the introduction and eventual crystallization of the interstitial phases. We do, however, have the additional and so far unique constraint of knowledge of the spatial context and, in particular, orientations of the hightemperature deformation fabrics in the geographical reference frame. 
This allows the first ever direct consideration of the geometry of mantle flow beneath an oceanic spreading center.

\section{Harzburgite Textural Types}

Two specimens of harzburgite from Hole 895D were selected for detailed fabric study: Sample 147-895D-3R-1 (Piece 8C, 64-69 cm) is representative of normal harzburgite, and Sample 147-895D-4R-3 (Piece 6A, 48-50 cm) is a clinopyroxene-bearing harzburgite. These specimens were selected for fabric studies because of their relatively low degree of serpentinization, which may even so reach $50 \%$. Both specimens contain spinel grains ( $0.5-2 \mathrm{~mm}$ in size), in close association with orthopyroxene, with a shape fabric (X:Z ratio $=\sim 2: 1)$ defining a moderately well-defined foliation (flattening) and lineation (elongation in the foliation plane). Olivine grains (3-10 mm) have a poor shape fabric, with lobate grain boundaries and rare, widely spaced, sharp sub-boundaries; locally, clusters of polygonal (1-3 $\mathrm{mm}$ ), neoblasts replace large porphyroclasts. These features are char- acteristic of highly annealed plastic deformation developed at hightemperature conditions. In clinopyroxene-bearing harzburgite Sample $147-895 \mathrm{D}-4 \mathrm{R}-3$ (Piece $6 \mathrm{~A}, 48-50 \mathrm{~cm}$ ), the olivine grain size is more homogeneous (Fig. 2A).

Orthopyroxene sometimes occurs in aggregates of elongated porphyroclasts exhibiting evidence of slip on their (100) plane, as marked by clinopyroxene exsolution (Fig. 2B). Most orthopyroxene aggregates contain recrystallized neoblasts 0.5 to $1 \mathrm{~mm}$ in size, similar to those described in the Garrett Fracture Zone specimens, and also characteristic of the upper mantle section in the Oman ophiolite at a level of $\sim 1 \mathrm{~km}$ below the Moho (Boudier and Coleman, 1981). The clinopyroxene-bearing harzburgite sample is relatively depleted in orthopyroxene, and those it does contain are characterized by smaller grain sizes. The orthopyroxene fabric (Fig. 3A, B) is of moderate intensity, marked by a maximum of the [001] slip direction at a low angle to the spinel lineation; some dispersion of [100] may possibly be caused by the development of the recrystallized neoblasts. This orthopyroxene fabric conforms to that normally observed in
A

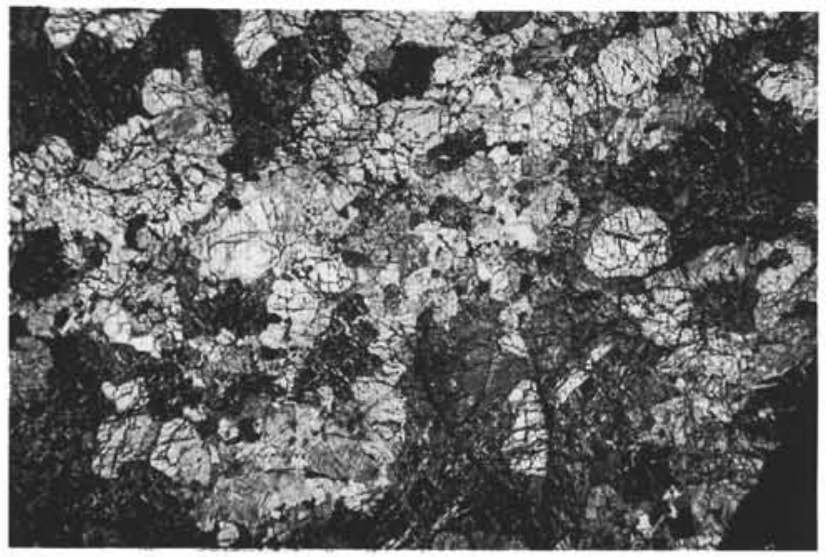

c

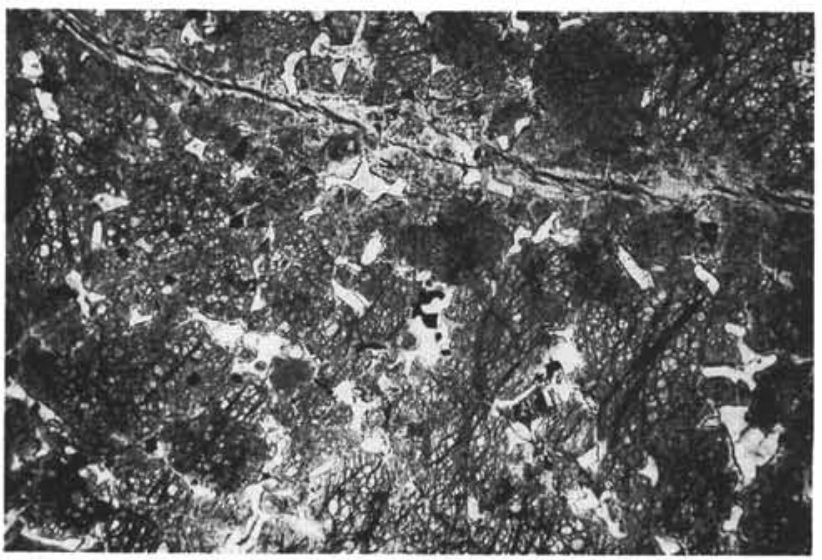

B

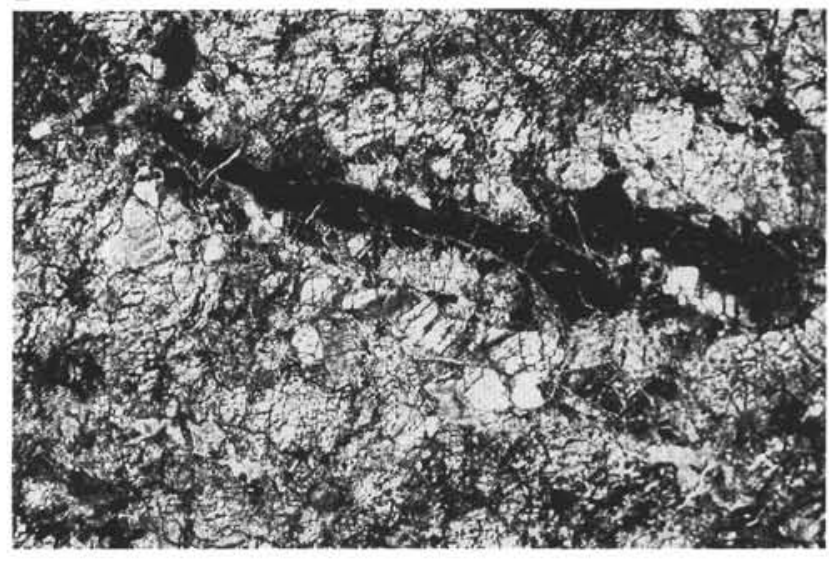

D

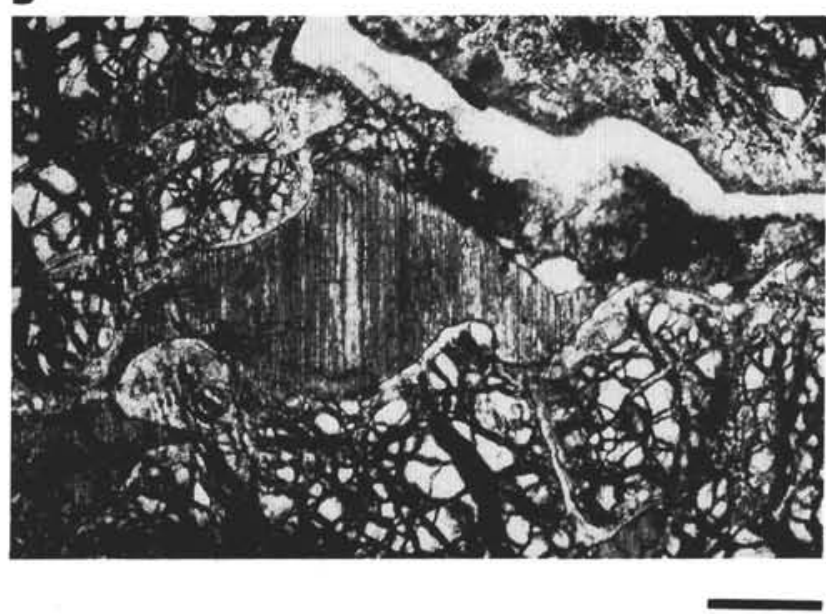

Figure 2. Photomicrographs of representative textures of Site 895 ultramafics. A. Rounded olivine neoblasts (1-3 mm), surrounded by interstitial clinopyroxene in harzburgite Sample 147-895D-4R-3 (Piece 6A, 48-50 cm); bar = $3 \mathrm{~mm}$. B. Porphyroclastic harzburgite with elongated orthopyroxene, partially recrystallized into 0.5 -mm neoblasts, surrounded by partly recrystallized olivine (1-3 mm), Sample 147-895D-5R-2 (Piece 2, 5-8 cm); bar $=3 \mathrm{~mm}$. C, D. Interstitial clinopyroxene and plagioclase isolating aggregates of rounded olivine in troctolite dunite, Sample 147-895C-4R-3 (Piece 3, 27-29 cm. Bar = 3 mm in Figure 2C and 5 $\mathrm{mm}$ in Figure 2D. 
[100]

A

B
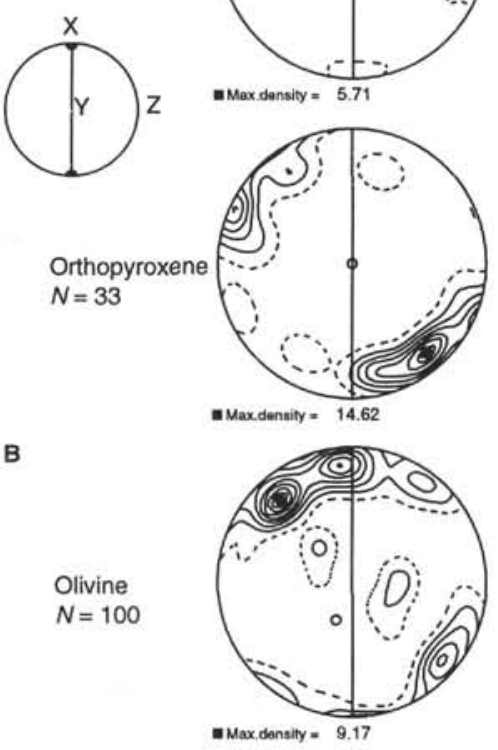

C
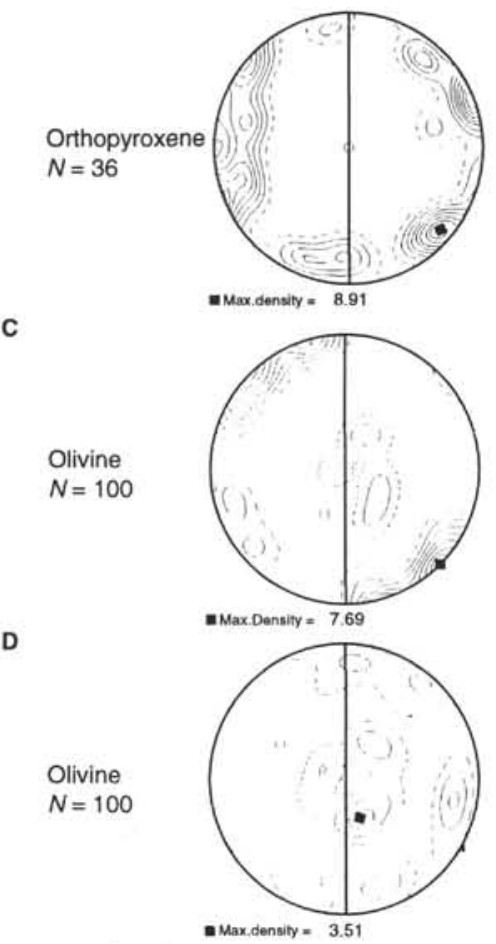

[010]
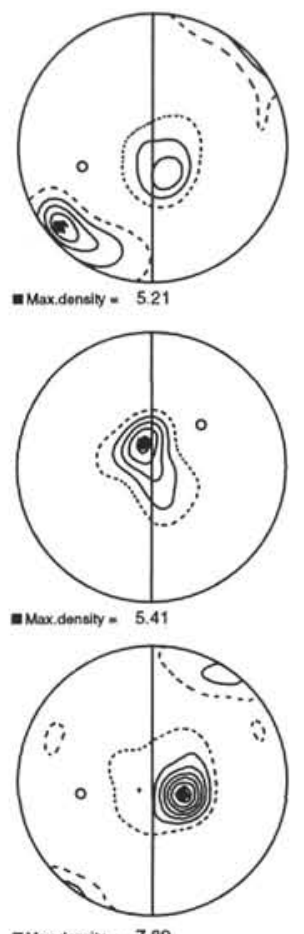

- Maxdensily = 7.89

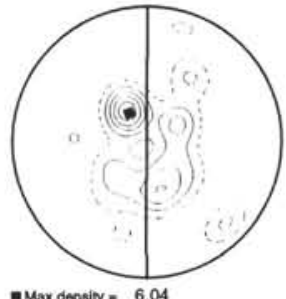

- Max densily = 6.04
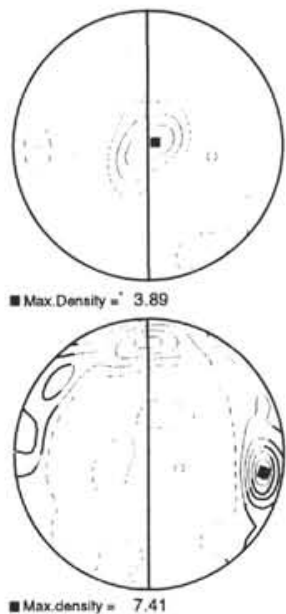

[001]
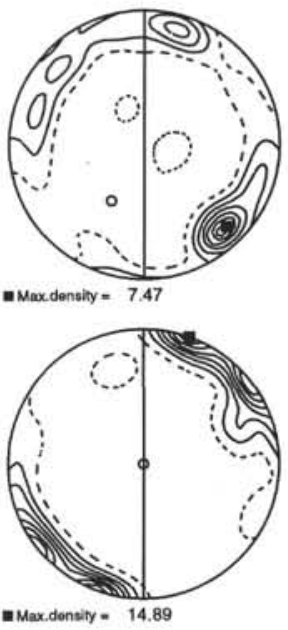

Max.donsily = 14.89
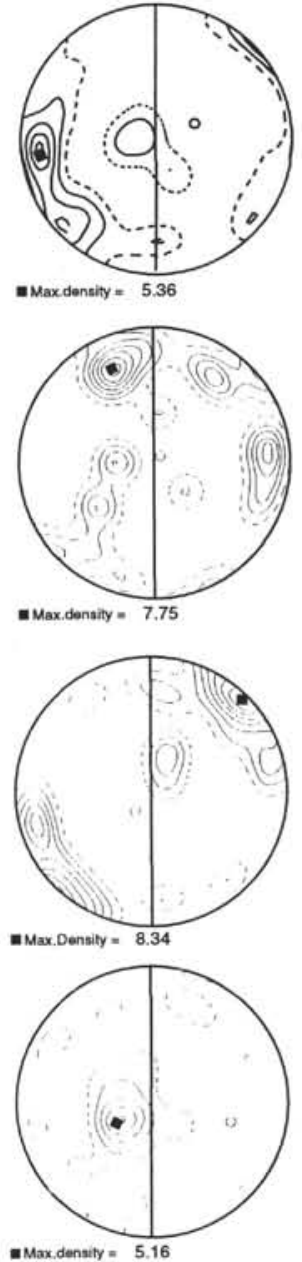

Figure 3. Mineral preferred orientation diagram for Site 895 peridotites. A. Harzburgite Sample 147-895D-3R-1 (Piece 8C, 64-69 cm). B. Harzburgite Sample 147-895D-4R-3 (Piece 6A, 48-50 cm). C. Dunite Sample 147-895E-6R-3 (Piece 1A, 0-3 cm). D. Troctolitic dunite Sample 147-895C-4R-3 (Piece 3, 0-3 cm). Lower hemisphere equal-area projection. Foliation plane is projected here as vertical and north-south, with the spinel lineation horizontal and north-south. $N=$ number of grains measured. Dashed line $=$ minimum contour; black square $=$ maximum value, for $1 \%$ area . 
mantle peridotites, and in some way constitutes an a posteriori validation of the foliation and lineation measurements conducted on the samples.

Olivine fabrics (Fig. 3A, B) are weak and complex; consistent with the poorly developed shape fabric that is observed. There is a tendency for [001] to form a maximum at low angle to the spinel lineation; also observed is a tendency for [010] to concentrate in the foliation plane. This type of fabric deviates from the common mantle fabric correlated with [100] $(010)$ or [100] (0kl) slip system (Nicolas and Poirier, 1976). Interestingly, the [010] maximum in the foliation plane is also observed in Garrett specimens (Cannat et al., 1990), in harzburgite specimens recording vertical mantle flow from the Maqsad diapir in Oman (D. Jousselin, unpubl. data, 1994), and in dunites enclosing chromite deposits in the New Caledonia ophiolite (Cassard, 1980). All of these are peridotites that are inferred to record asthenospheric flow on top of mantle upwelling, where plastic deformation develops in presence of melt percolation (Rabinowicz at al., 1987). Under these conditions, which might be expected to favor diffusion, dislocation climb could be promoted over dislocation glide, and thus give rise to this somewhat atypical fabric.

\section{Dunite and Troctolite Textural Type}

Dunites sensu stricto or "dry" dunites, composed of olivine and spinel, are badly serpentinized (generally more than 90\%) in Site 895 samples. Some specimens contain olivine fragments of millimeter size in the serpentine network, so that it is possible to visualize the primary texture in polarized light. This is the case for the selected Sample 147-895E-6R-3 (Piece 1A, 0-3 cm) serpentinized 70\%. Sample 147-895C-4R-3 (Piece 3, 0-3 cm) serpentinized 70\%, is classified as a troctolitic dunite because it contains plagioclase patches, associated with spinel, in an interstitial position between rounded to idiomorphic olivine grains. This "troctolitic dunite" rock type has been also collected in the Garrett Fracture Zone. In the Hess Deep cores, transitions between "dry" dunite and troctolite are observed through increasing amount of interstitial plagioclase (Gillis, Mével, Allan, et al., 1993).

All these rocks have similar textural characteristics (Fig. 2C, D). Olivine is rounded with little shape anisotropy; rare, sharp, widespaced sub-boundaries are observed. Grain size is 2 to $10 \mathrm{~mm}$ in dunite sensu stricto, larger at 10 to $20 \mathrm{~mm}$ in troctolite. Clusters of polygonal olivine neoblasts develop locally. Despite the olivine shape isotropy, the spinel has a shape fabric $(\mathrm{X}: \mathrm{Z}$ ratio $=\sim 2: 1)$. Treated as a strain marker, spinel records deformation of the same order as observed in the harzburgite specimens. Therefore, the low shape anisotropy of the olivines must be accounted for by a high rate of recovery.

The strong olivine fabrics in the dunite (Fig. 3C) provide evidence for plastic strain; once again the olivine fabric is marked by a [010] maximum in the foliation plane, and the strong [100] maximum at low angle to the spinel lineation is consistent with the high-temperature [100] slip direction. The troctolitic dunite has a weak but "normal" mantle fabric with a [100] dispersion in the foliation plane and a weak [010] maximum perpendicular to the foliation. Until now, few comparable fabrics concerning these rock types have been reported: Cannat et al. (1990) also found weak normal fabrics for plagioclase dunites from Garrett, and slightly stronger normal fabrics were documented by Boudier and Nicolas (1995) for a foliated troctolite from the Moho transition zone of the Oman ophiolite.

For the Site 895 samples, as previously documented for the Garrett and Nautile samples from the Hess Deep, the interstitial clinopyroxene and plagioclase are absolutely devoid of deformation: no trace of slip is observed on the (100) clinopyroxene glide plane and, thus, no lattice deformation.

\section{Dislocation Patterns}

Dislocations in olivine were decorated by the classical method of iron oxidation (Kohlstedt et al., 1976) and observed with optical microscopy at magnitude $1000 \times$ in harzburgite Sample 147-895D-4R-3 (Piece 6A, 48-50 cm) and in dunite Sample 147-895E-6R-3 (Piece $1 \mathrm{~A}, 0-3 \mathrm{~cm}$ ). In both samples, the dislocation pattern continues on each side of the network of serpentine; the constancy of this observation confirms that the pervasive serpentinization is absolutely static and does not affect the high-T fabric of peridotites. The density of dislocations is high in both specimens. This result is unexpected, considering the high rate of recovery observed at low magnifications. The common dislocation pattern, as identified on the universal stage, is composed of (001) walls linked with [001] screw dislocations (Fig $4 \mathrm{~A}, \mathrm{~B})$, suggesting that the dislocation pattern records intracrystalline slip along the [001] slip direction, which is the Burgers vector acting at lower temperature and higher strain rates than those prevailing in asthenospheric conditions (Nicolas and Poirier, 1976). Consideration of the crystallographic preferred orientations, and the high rate of recovery at the textural scale, suggest that the dislocation pattern postdates the development of the crystallographic fabric and annealing. It has an independent signature and probably records stress developed
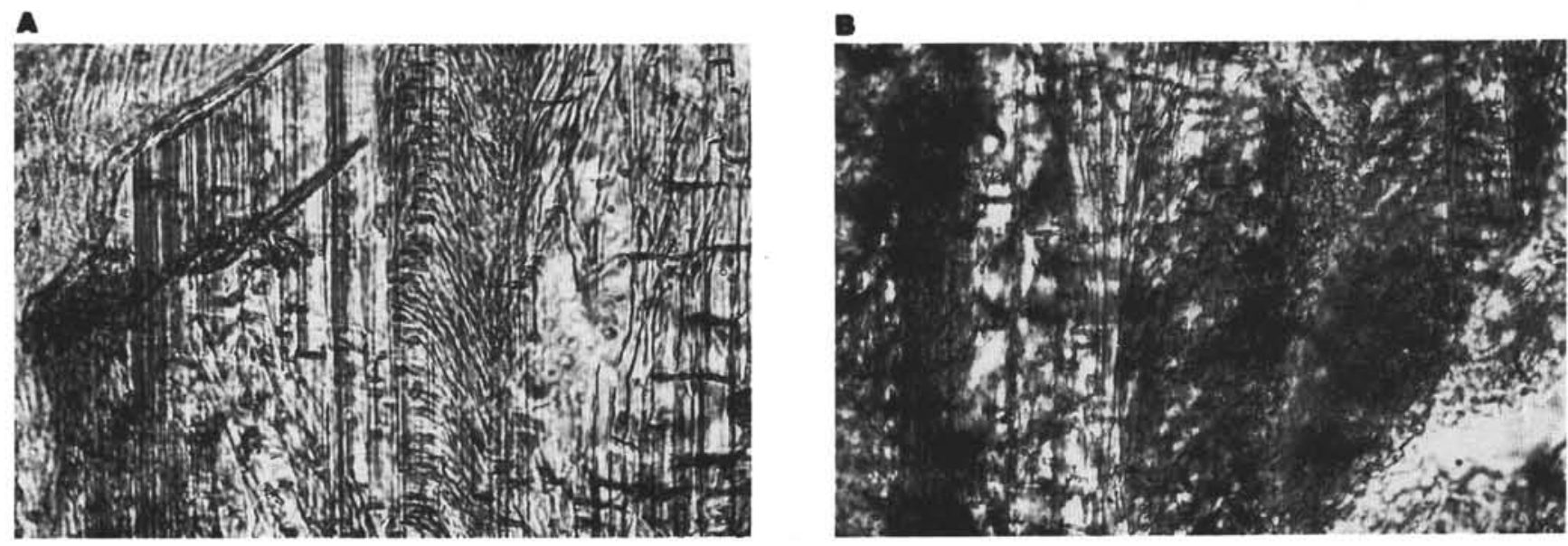

Figure 4. Dislocation substructure in deformed olivine. A. Harzburgite Sample 147-895D-4R-3 (Piece 6A, 48-50 and 37-94 cm); [001] screw dislocations join (001) walls; bar $=10 \mu \mathrm{m}$. B. Dunite Sample 147-895E-6R-3 (Piece 1A, 0-3 cm); bar $=10 \mu \mathrm{m}$. 
in lithospheric conditions. Interestingly, the [001] maximum observed in the harzburgite fabrics (Fig. 3A, B) is not inconsistent with a contribution of the [001] slip direction. Thus, the dislocation pattern could record a stress episode postdating but in continuity with the asthenospheric mantle flow (see also Kennedy et al., this volume). Similar dislocation patterns observed in troctolites, dunites, and harzburgites (Kennedy et al., this volume) provide further evidence for a residual origin to the olivine crystal component of these ultramafics.

\section{Seismic Properties}

The seismic properties of a rock can be calculated if one knows the modal analysis, the single crystal elastic constants, and the density and crystallographic fabric of each component (Mainprice, 1990). Seismic anisotropy is caused not only by preferred orientations of minerals, but also by cracks and modal layering. Unlike compressional-wave velocities measured directly on specimens, calculated wave velocities only account for mineral orientations. Furthermore, calculated wave velocities also include $S$-waves and are directly related to the crystallographic fabrics, providing maximum and minimum velocity values and velocity anisotropy, which can be compared directly with large-scale sonobuoy data from the oceanic lithosphere (e.g., Blackman et al., 1993).

Seismic $P$ - and $S$-wave velocities and seismic anisotropy were computed at in situ conditions (Fig. 5) on the basis of crystallographic fabrics (Fig. 3) for the four specimens studied. Modal analyses were taken from Gillis, Mével, Allan, et al. (1993). The $V_{p}$ maximum varies from 9.06 to $9.23 \mathrm{~km} / \mathrm{s}$, whereas the $V_{p}$ minimum is between 8.47 and $8.62 \mathrm{~km} / \mathrm{s}$. As explained above, these values are valid for mantle rocks that possess the observed fabrics and are devoid of serpentinization. They are $10 \%$ higher than the standard values of $8.2-8.3$ $\mathrm{km} / \mathrm{s}$ deduced from sonobuoy data for suboceanic mantle. Further, they are significantly higher than velocities obtained from direct measurements on cores of serpentinized peridotites (Gillis, Mével, Allan, et al., 1993; Iturrino, this volume). The role of temperature must also be taken into account: a $1000^{\circ} \mathrm{C}$ temperature elevation should decrease the $P$-wave velocity by about $0.5 \mathrm{~km} / \mathrm{s}$, as extrapolated from experimental data (Kern and Wenk, 1985). The $V_{p}$ velocities are controlled by the olivine fabric (with the $V_{p}$ maximum parallel to [100]ol, and the $V_{p}$ minimum parallel to [010]ol). This is also indicated by the narrow range of variations for maximum and minimum values in harzburgite, dunite, and troctolitic dunite. The $S$-wave birefringence is more sensitive to the influence of other phases; the minimum birefringence is correlated with crystallographic fabrics of olivine and orthopyroxene, and the maximum value is lower in troctolitic dunite (Fig. 5).

\section{ORIENTATIONS OF FABRICS Methodology}

Measurement of the orientations of the fabrics described above was made on the cores both during and after the cruise. Traces of a foliation, principally defined by elongation of spinel and, to a lesser extent, orthopyroxene, were identified using a binocular microscope on the surfaces of the core. Planes were reconstructed from two apparent dip measurements, in some cases also with a strike measurement from horizontal surfaces, in the manner described by MacLeod et al. (1994) and Gillis, Mével, Allan, et al. (1993). Identification of a lineation was rarely possible in hand specimen, other than to note that the fabric was stronger in certain directions than in others. Measurements were verified where possible by detailed laboratory examination of oriented thin sections. Preliminary cuts made parallel to the foliation provided favorably oriented sections for identification of a lineation; thin sections were then made parallel to this lineation, both parallel and perpendicular to the foliation.
Fabric orientations were measured using the procedure described by MacLeod et al. (1994) and summarized in Gillis, Mével, Allan, et al. (1993). The axis of the borehole was considered to be vertical (no borehole deviation measurements were made at Site 895), and azimuths were measured relative to artificial "coreliner coordinates": "north" was defined as perpendicular to the cut surface and lying in the working half of the core. Restoration of the core fabric measurements to a common reference frame was made by rotating the stable magnetic remanence direction measured in the same contiguous core pieces (Gillis, Mével, Allan, et al., 1993) to the same horizontal direction. In the present case, a second rotation was then made to bring the measurements to a common magnetic inclination (of $+4.6^{\circ}$ ) as well as declination. Inclinations of the stable remanence directions at Hole $895 \mathrm{E}$ are consistently skewed by approximately $35^{\circ}-40^{\circ}$ down toward the declination direction (Gillis, Mével, Allan, et al., 1993) when compared to the expected field direction for the drill-site latitude (i.e., $+4.6^{\circ}$ ). This disparity in inclinations is identical to that found in the gabbroic rocks of Site 894 and is most readily interpreted in terms of a tectonic rotation (probably of the entire intra-rift ridge) with a horizontal component of this magnitude (MacLeod, Célérier, et al., this volume). At Hole $895 \mathrm{D}$, inclinations were far more scattered, which may indicate that the drilled section was significantly disrupted, perhaps because of the location of the site close to a fault zone (MacLeod, Célérier, et al., this volume).

Restoration of the samples relative to the stable magnetic remanence direction assumes that all of the samples acquired their magnetizations in the same field direction and, if this direction is equated with geographic north, that there has been no rotation of the sample before magnetization. In the present case, the latter assumption cannot be proven, and is not necessarily totally justified, because the "primary" remanence is carried by magnetite formed during serpentinization (Gillis, Mével, Allan, et al., 1993; Kelso et al., this volume). Nevertheless, the dispersion of inclinations suggests that some rotation has certainly occurred after magnetization; and, thus, it is more relevant to consider the orientations of the peridotite fabrics (which necessarily predate acquisition of the "primary" remanence) restored relative to a common magnetic declination and inclination direction. Although this restoration does not tell us the present-day orientation of the cores as they were immediately before drilling, in the absence of logging data (and consequent azimuthal reorientation of cores to present-day geographical coordinates; MacLeod et al., 1994; MacLeod, Boudier, et al., this volume; MacLeod, Célérier, et al., this volume), it does provide us with the best estimate of the original orientations of fabrics relative to the ridge reference frame, because the angular relationships between the fabrics and remanence direction is unlikely to have changed.

\section{Results}

The restored strikes of the peridotite foliations (Fig. 6A) show a moderate north-south to north-northeast-south-southwest preferred trend. Stereographic projections of the poles of these planes show an overall girdle about a north-south, subhorizontal axis, indicating that there is a much greater range of dips to the foliations than strikes (Fig. $6 \mathrm{~B})$. Given the greater uncertainties inherent in recalculating strikes from apparent dip data (MacLeod et al., 1994), we do not think that the dispersion of strikes is significant; instead, the strikes will all be regarded as more or less north-south, within the resolution of our measurements. In contrast, the restored lineation measurements, at least when considered together, show a range of orientations, with no immediately apparent preference for either steep or shallow plunges (Fig. 7).

Subdividing the foliation measurements by lithology (Fig. 8), it is obvious that the dunites have a greater dispersion of orientations, particularly of dip; in contrast, the harzburgites show much more consistent orientations. Figures 9 and 10 show that, although the harzburgites are generally steeply dipping throughout, dunites from the mas- 

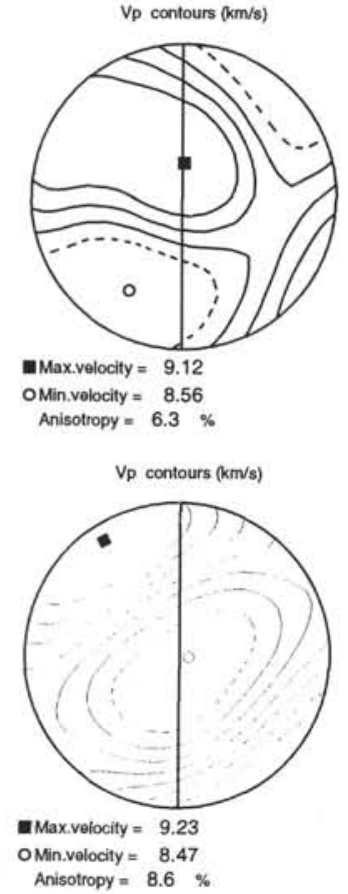

c

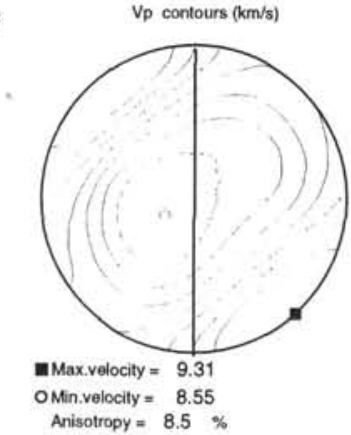

Anisotropy $=8.5 \%$

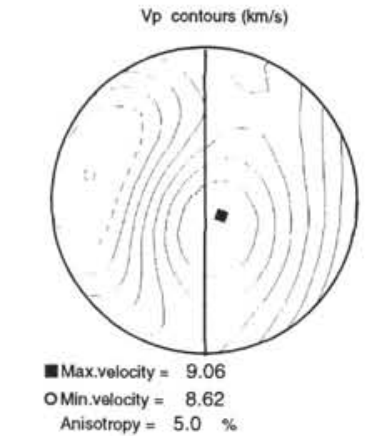

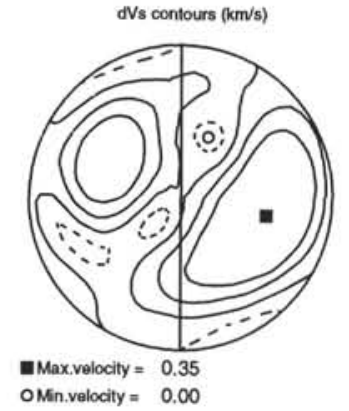

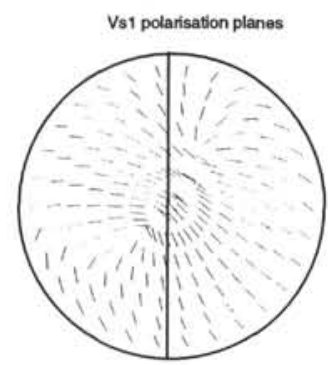

Min.velocity $=0.00$
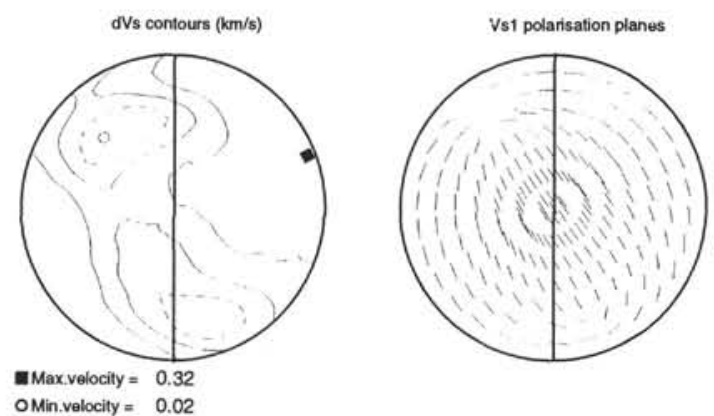

OMin velocity $=0.02$
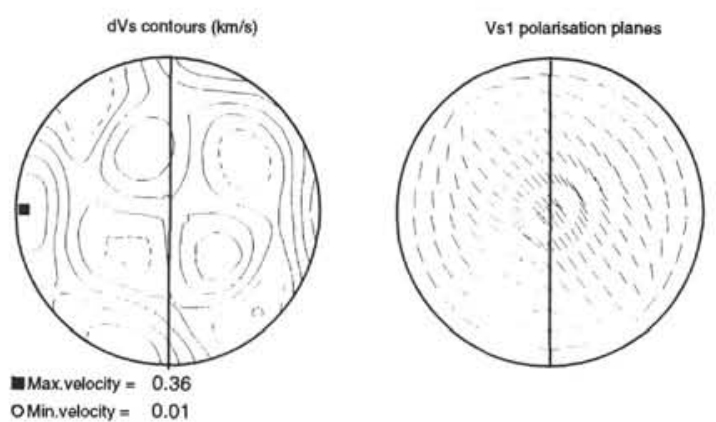

Min.
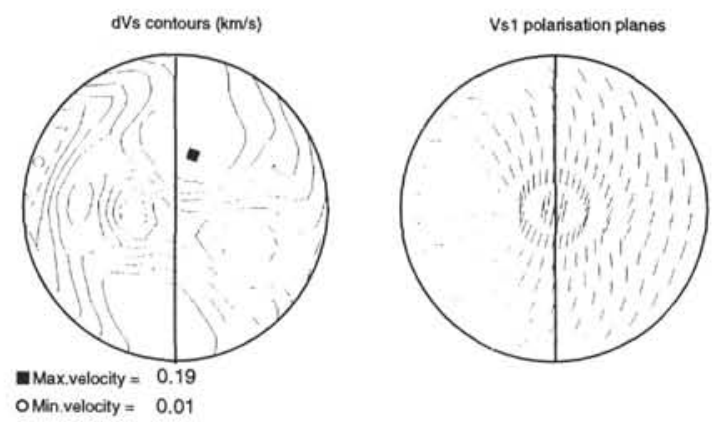

Figure 5. Seismic velocities, $P$ - and $S$-waves, computed from the crystallographic fabrics of Figure 3 , and from the following modal compositions. A. Sample 147-895D-3R-1 (Piece 8C, 64-69 cm), olivine $=75 \%$, orthopyroxene $=24 \%$, and spinel $=$ $1 \%$. B. Sample 147-895D-4R-3 (Piece 6A, 48-50 $\mathrm{cm})$, olivine $=85 \%$, orthopyroxene $=14 \%$, clinopyroxene $=1 \%$, and spinel $=<1 \%$. C. Sample 147 895E-6R-3 (Piece 1A, 0-3 cm), olivine $=98 \%$, spinel 2\%. D. Sample 147-895C-4R-3 (Piece 3, 0-3 $\mathrm{cm})$, olivine $=85 \%$, plagioclase $=10 \%$, clinopyroxene $=5 \%$, and spinel $=<1 \%$. Same reference system as Figure 3. sive dunite section in the uppermost $40 \mathrm{~m}$ of Hole $895 \mathrm{E}$ show a systematic decrease of foliation dip upsection. We tentatively noted this relationship in Gillis, Mével, Allan, et al. (1993) on the basis of ten samples; with the laboratory measurements presented here for Hole $895 \mathrm{E}(N=35)$, the observation is confirmed and the trend strengthened. Wherever harzburgites and dunites occur together in Hole $895 \mathrm{E}$, we note that they show similar ranges of dip variation at a given depth.

The lineation data show less consistency (Fig. 7), although this may be a function of the greater difficulty in measuring lineations than foliations. However, we do note a systematic decrease in the plunge of the flow lineation upsection through Hole 895D, although the foliation remains steeply dipping and strikes almost north-south (Figs. 8B, 10). This implies a steep flow trajectory at depth, turning to become shallower closer to the surface. In Hole 895E, the lineation plunge becomes shallower as the planes dip less steeply, and there is a spread of plunge azimuths.

\section{DISCUSSION}

\section{Crust/Mantle Transition Zone}

As demonstrated by previous authors (Cannat et al., 1990; Girardeau and Francheteau, 1993), the still limited suite of ultramafic 
A

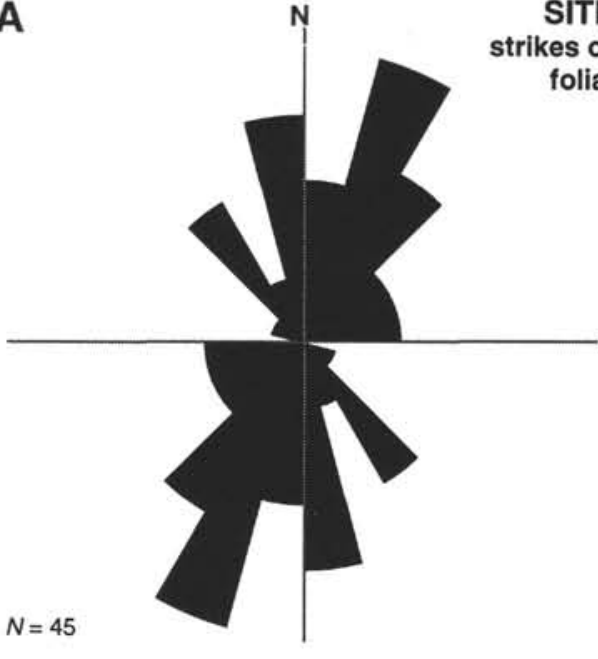

SITE 895 stored liations
B

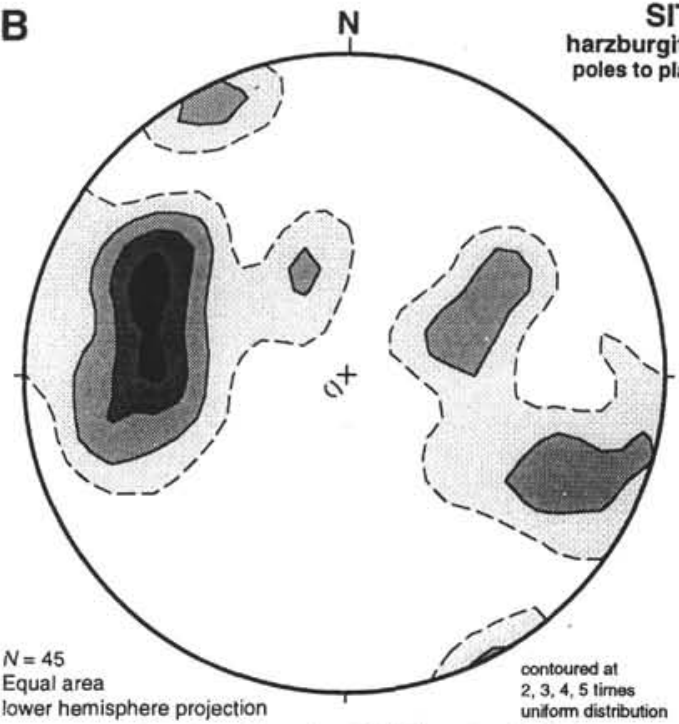

SITE 895 zburgites and dunites es to planes of foliations

Figure 6. A. Rose diagram of the strikes of foliations measured from macroscopic core samples (data plotted as if bidirectional). B. Contoured, lower hemisphere, equal-area projection of the poles to planes of harzburgites and dunites from all holes at Site 895 . The restored poles display a broad girdle about a near north-south, subhorizontal axis; the dispersion of dips of the planes is greater than the dispersion in strikes.

rocks collected from the East Pacific Rise are mantle peridotites composed of olivine (with or without orthopyroxene), plastically deformed and with strained spinel. This deformation took place under asthenospheric conditions at very high temperatures, or at least in the presence of partial melt, which had the effect of enhancing lattice recovery. Partial melt percolation is attested to by the occurrence of interstitial phases that crystallized after the plastic deformation of the peridotite frame. An important implication of this is that, at least in the harzburgites, melt impregnation preserved the solid state fabric, and thus the rock did not disaggregate. Only locally did a "breccia" (represented by the troctolitic dunites) form. Detailed studies of the Moho transition zone in the Oman ophiolite show that similar textures exist there, with evidence for the localized disruption and partial destruction of the solid-state framework in instances where the proportion of melt infiltration was sufficiently large (Boudier and Nicolas, 1995).

In addition to the textural record, Hess Deep Site 895 has provided first-order information on the structural and lithostratigraphic relationship between lithologies on a meter to hundred-meter scale. Holes 895C, 895D, and 895E have shown that stratification of the observed lithologies may exist on a scale of tens of centimeters to tens of meters, with the general relationship harzburgite-dunite-troctolitedunite-harzburgite (Gillis, Mével, Allan, et al., 1993). Once again, reference to ophiolites, particularly Oman, has shown that the maficultramafic components of the Moho transition zone are stratified on a similar scale (Pallister and Hopson, 1981; Browning, 1982; Benn et al., 1988; Ceuleneer et al., 1988; Ceuleneer, 1991; Boudier and Nicolas, 1995). These last four studies have shown that the thickness of the dunite-dominated Moho transition zone in Oman varies widely, from some hundreds of meters directly above a zone of ascending mantle flow, to as little as a few meters at a distance of $20-30 \mathrm{~km}$ away. They have further shown that dunites in the diapiric areas are little-deformed, but that strains increase dramatically away from them as the dunites are compacted and the thickness of the transition zone decreases.

\section{Geometry of Mantle Fabrics}

Forty-five measurements of the plastic deformation fabrics in Site 895 mantle peridotites have been restored to geographical coordinates using paleomagnetic data; of these, lineation measurements have been made on 27 . The geometry of the fabrics in the harzburg- ites, with a flow plane trending parallel to the EPR and steeply dipping, suggests that mantle flow recorded in the fragment of lithosphere drilled at Site 895 (across a lateral distance of some $500 \mathrm{~m}$ ) relates to accretion beneath the EPR. The dispersion of the measured lineations makes the three-dimensional geometry difficult to constrain; however, the steep flow trajectories imply near-vertical upwelling beneath the axis, and hence the possibility that the preserved structures may represent the fossilized trace of part of a mantle diapiric structure.

Most dramatic of all is the marked change within the massive dunites of Hole 895E from steep to subhorizontal flow trajectories upsection, taking place progressively over the space of a few tens of meters. Fabrics within the massive dunites are weak and less regular than in the harzburgites; they show widely scattered flow lineation directions, the majority of which trend at a high angle to the ridge strike. We interpret the massive dunites to be part of a Moho transition zone above a zone of mantle upwelling, within which the overturn from predominantly vertical ("diapiric") to predominantly horizontal mantle flow takes place. The similarities with the geological relationships observed in the diapiric zones in Oman (e.g., Maqsad: Ceuleneer, 1991; Boudier and Nicolas, 1995) is striking: only in such zones do massive dunites occur, and it is only such zones that are characterized by extensive melt impregnation structures and uncharacteristically weak deformation fabrics. Indeed, the "overturn" within these diapiric zones in Oman and in the top of Hole 895E can be regarded more as a case of the disappearance of the steep fabric and reestablishment of a shallow one, rather than as a progressive rotation.

The above interpretation of the Site 895 fabrics begs the question why such diapiric structures should be preserved in $\sim 1$-m.y.-old lithosphere, some $60 \mathrm{~km}$ from the ridge axis, rather than being destroyed by subsequent horizontal divergent flow. In general, we do not yet know whether the process of diapirism is essentially episodic or steady state, especially not beneath fast-spreading ridge axes. Nor do we know whether diapirism, if episodic, would obliterate all trace of previous upwelling, especially at ridge axial terminations. For Site 895 , however, the simplest explanation for the preservation of the observed flow geometry is that because the Hess Deep rifting, and hence the exhumation and cooling of the subcrustal shallow mantle, took place so soon after accretion at the EPR, the original crust/mantle boundary was isolated from the effects of off-axis horizontal flow and the subaxial structures were accordingly frozen in. Although the 

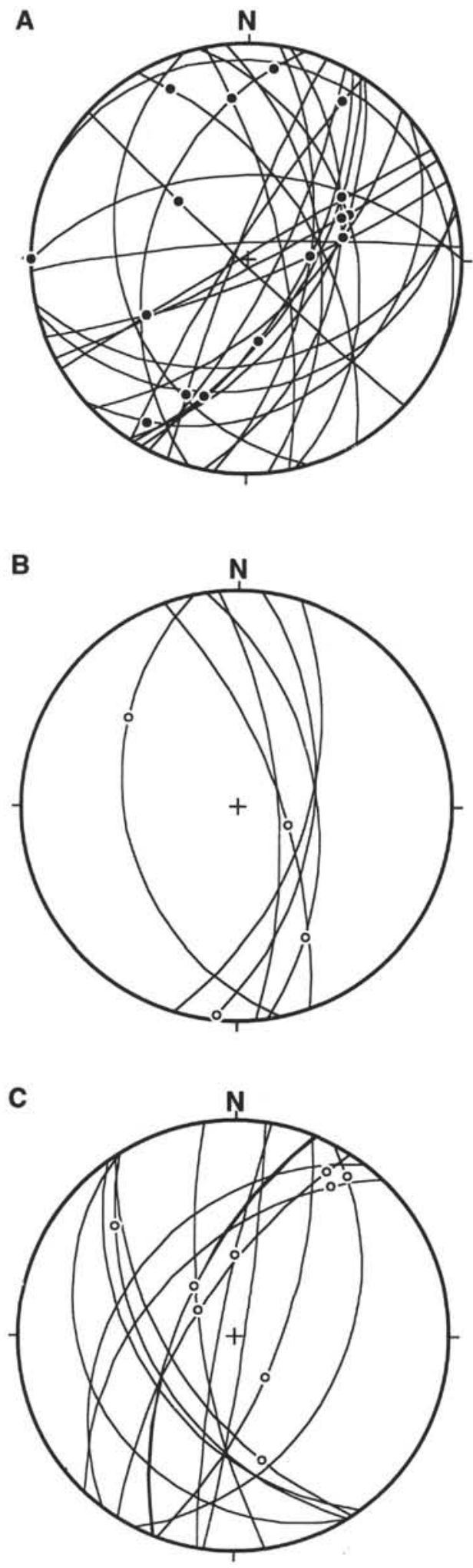

Equal area lower hemisphere projections All corrected relative to a common declination and inclination

Figure 7. A. Equal-angle lower hemisphere stereogram of foliations and associated lineations in dunites from Hole 895E. B. Stereogram of foliations and lineations for harzburgites in Hole 895E. C. Stereogram of foliations and lineations for harzburgites from Holes 895B, 895C, and 895D.
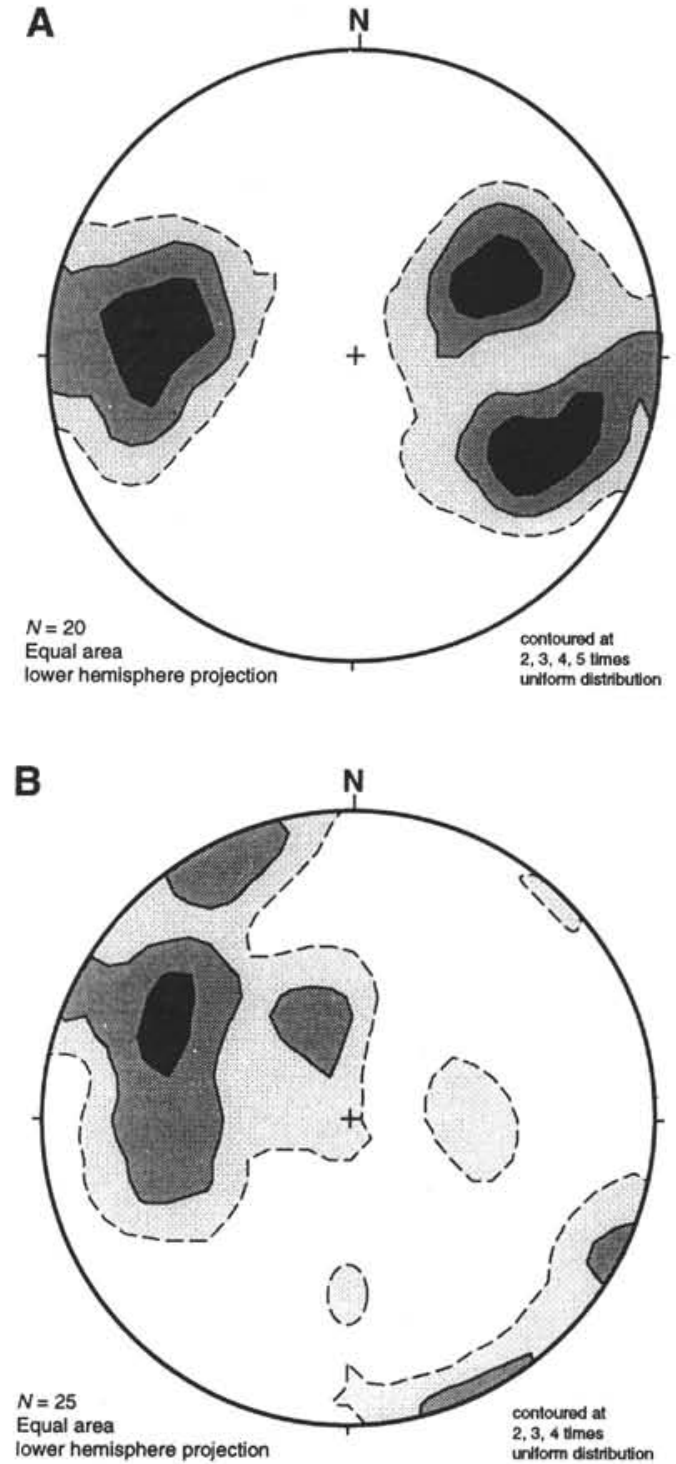

Figure 8. Contoured, lower hemisphere, equal-area projection of the poles to planes of harzburgites (A) and dunites (B) from all holes at Site 895. Note the greater scatter in orientations of the restored planes in the dunites and the occurrence of some subhorizontal foliations.

flow geometry preserved in the shallow mantle of Hess Deep as sampled at Site 895 may not be typical, therefore, of that found $60 \mathrm{~km}$ away from the EPR elsewhere along the ridge (in nonrifted lithosphere), it can still be regarded as representative of the on-axis geometry of upwelling beneath a "typical" portion of the EPR.

\section{REFERENCES}

Benn, K., Nicolas, A., and Reuber, I., 1988. Mantle-crust transition zone and origin of wehrlitic magmas: evidence from the Oman ophiolite. Tectonophysics, 151:75-85.

Blackman, D.K., Orcutt, J.A., Forsyth, D.W., and Kendall, J.M., 1993. Seismic anisotropy in the mantle beneath an oceanic spreading centre. $\mathrm{Na}$ ture, 366:675-677.

Boudier, F., and Coleman, R.G., 1981. Cross section through the peridotite in the Samail ophiolite, southeastern Oman Mountains. J. Geophys. Res., 86:2573-2592.

Boudier, F., and Nicolas, A., 1995. Nature of the Moho Transition Zone in the Oman ophiolite. J. Petrol., 36:777-796.

Browning, P., 1982. The petrology, geochemistry and structure of the plutonic rocks of the Oman ophiolite [Ph.D. thesis]. Open Univ., London. 
1984. Cryptic variation within the Cumulate Sequence of the Oman ophiolite: magma chamber depth and petrological implications. In Gass, I.G., Lippard, S.J., and Shelton, A.W. (Eds.), Ophiolites and Oceanic Lithosphere. Geol. Soc. Spec. Publ. London, 13:71-82.

Cannat, M., 1991. Plastic deformation at an oceanic spreading ridge: a microstructural study of Site 735 gabbros (southwest Indian Ocean). In Von Herzen, R.P., Robinson, P.T., et al., Proc. ODP, Sci. Results, 118: College Station, TX (Ocean Drilling Program), 399-408.

Cannat, M., Bideau, D., and Hébert, R., 1990. Plastic deformation and mag matic impregnation in serpentinized ultramafic rocks from the Garret transform fault (East Pacific Rise). Earth Planet. Sci. Lett., 101:216-232.

Cassard, D., 1980. Structure et origine des gisements de chromite du massif du Sud (ophiolite de Nouvelle Calédonie), Guides de prospection [Thèse de 3ème cycle]. Univ. Nantes, Nantes.

Ceuleneer, G., 1991. Evidences for a paleo-spreading center in the Oman ophiolite: mantle structures in the Maqsad area. In Peters, T., Nicolas, A., and Coleman, R.G. (Eds.), Ophiolite Genesis and Evolution of Oceanic Lithosphere: Dordrecht (Kluwer), 147-173.

Ceuleneer, G., Nicolas, A., and Boudier, F., 1988. Mantle flow patterns at an oceanic spreading centre: the Oman peridotite record. Tectonophysics. 151:1-26.

Dick, H.J.B., and Bullen, T., 1984. Chromian spinel as a petrogenetic indicator in abyssal and alpine-type peridotites and spatially associated lavas. Contrib. Mineral. Petrol., 86:54-76.

Francheteau, J., Armijo, R., Cheminée, J.L., Hekinian, R., Lonsdale, P., and Blum, N., 1990. 1 Ma East Pacific Rise oceanic crust and uppermost mantle exposed by rifting in Hess Deep (equatorial Pacific Ocean). Earth Planet. Sci. Lett., 101:281-295.

Gillis, K., Mével, C., Allan, J., et al., 1993. Proc. ODP, Init. Repts., 147: College Station, TX (Ocean Drilling Program).

Girardeau, J., and Francheteau, J., 1993. Plagioclase-wehrlites and peridotites on the East Pacific Rise (Hess Deep) and the Mid-Atlantic Ridge (DSDP Site 334): evidence for magma percolation in the oceanic upper mantle. Earth Planet. Sci. Lett., 115:137-149.

Hébert, R., Bideau, D., and Hekinian, R., 1983. Ultramafic and mafic rocks from the Garret transform fault near $13^{\circ} 30^{\prime} \mathrm{S}$ on the East Pacific Rise: igneous petrology. Earth Planet. Sci. Lett., 65:107-125.

Hekinian, R., Bideau, D., Francheteau, J., Cheminée, J.L., Armijo, R., Lonsdale, P., and Blum, N., 1993. Petrology of the East Pacific Rise crust and upper mantle exposed in the Hess Deep (eastern equatorial Pacific). $J$ Geophys. Res., 98:8069-8094.

Hey, R., Johnson, G.L., and Lowrie, A., 1977. Recent plate motions in the Galapagos area. Geol. Soc. Am. Bull., 88:1385-1403.

\section{Hole 895E}

Dip of foliation $\left({ }^{\circ}\right)$

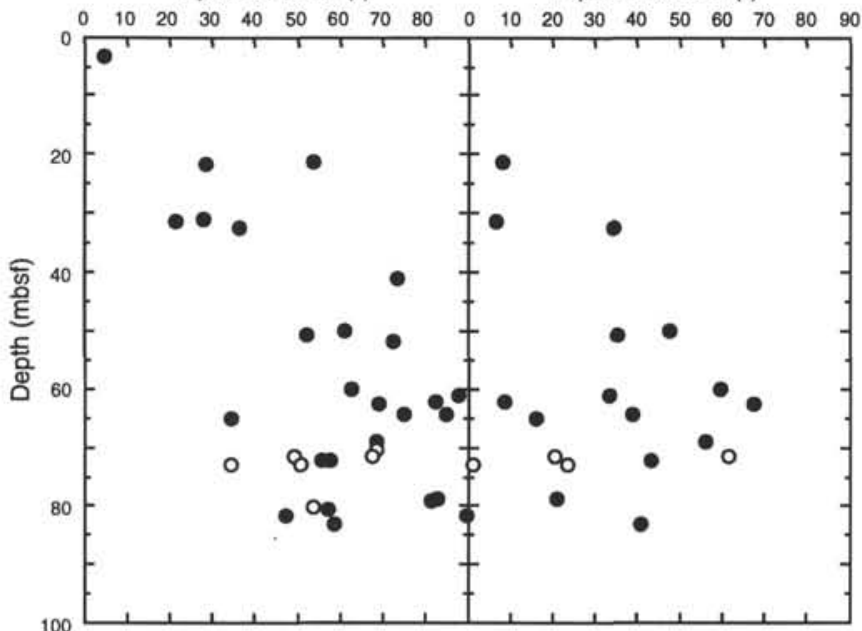

Figure 9. Dips of foliation and plunges of lineation measurements vs. depth in Hole 895E. Dunites are shown in black, and harzburgites in white. Note the decrease in dip of the foliation upsection (and the concomitant decrease in lineation plunge). For discussion, see text.
Johnson, J.L., Vogt, P.R., Hey, R., Campsie, J., and Lowrie, A., 1976. Morphology and structure of the Galapagos Rise. Mar. Geol., 21:81-120.

Kashintsev, G.L., Kuzmin, M.I., and Popolitov, E.N., 1982. Composition and structure of the oceanic crust in the vicinity of the Hess basin (Pacific Ocean). Geotectonics, 16:512-520.

Kern, H., and Wenk, H., 1985. Anisotropy in rocks and the geological significance. In Wenk, H. (Ed.), Preferred Orientation in Deformed Metals and Rocks: An Introduction to Modern Texture Analysis: Orlando, FL (Academic Press), 537-555.

Kohlstedt, D.L., Goetze, C., Durham, W.B., and Sande, J.V., 1976. A new technique for decorating dislocations in olivine. Science, 191:1045-1046.

Lonsdale, P., 1988. Structural pattern of the Galapagos microplate and evolution of the Galapagos triple junction. J. Geophys. Res., 93:13551-13574.

MacLeod, C.J., Parson, L.M., and Sager, W.W., 1994. Reorientation of cores using the Formation MicroScanner and Borehole Televiewer: application to structural and paleomagnetic studies with the Ocean Drilling Program. In Hawkins, J., Parson, L., Allan, J., et al., Proc. ODP, Sci. Results, 135: College Station, TX (Ocean Drilling Program), 301-311.

Mainprice, D., 1990. An efficient Fortran program to calculate seismic anisotropy from the lattice preferred orientation of minerals. Comput. Geosci., 16:385-393.

Nicolas, A., 1986. Structure and petrology of peridotites: clues to their geodynamic environment. Rev. Geophys., 24:875-895.

Nicolas, A., and Boudier, F., 1995. Mapping mantle diapirs and oceanic crust segments in Oman ophiolites, J. Geophys. Res., 100:6179-6197.

Nicolas, A., and Poirier, J.-P., 1976. Crystalline Plasticity and Solid State Flow in Metamorphic Rocks: New York (Wiley).

Pallister, J.S., and Hopson, C.A., 1981. Samail ophiolite plutonic suite: field relations, phase variation, cryptic variation and layering, and a model of a spreading ridge magma chamber. J. Geophys. Res., 86:2593-2644.

Rabinowicz, M., Ceuleneer, M., and Nicolas, A., 1987. Melt segregation and flow in mantle diapirs below spreading centers: evidence from the Oman ophiolites. J. Geophys. Res., 92:3475-3486.

Searle, R.C., and Francheteau, J., 1986. Morphology and tectonics of the Galapagos triple junction. Mar. Geophys. Res., 8:95-129.

Date of initial receipt: 4 August 1994

Date of acceptance: 5 January 1995

Ms 147SR-021

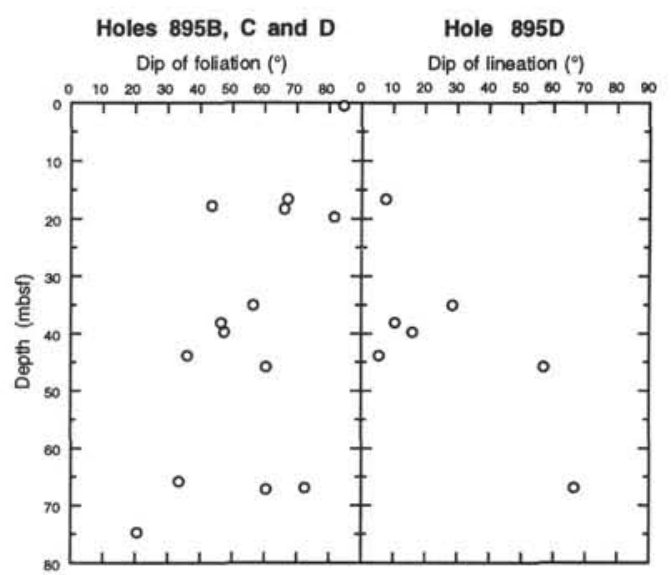

Figure 10. Dips of foliation and plunges of lineation measurements vs. depth in harzburgites from Hole $895 \mathrm{D}$. No systematic change of foliation dip with stratigraphic position is observed; however, the plunge of the lineation does decrease. For discussion, see text. 